DOI: http://dx.doi.org/10.18203/2320-1770.ijrcog20173462

Original Research Article

\title{
Intravenous versus oral iron therapy in treatment of postpartum anaemia
}

\author{
Neelima Agarwal*, Preeti Sharma
}

Department of Obstetrics and Gynecology, Santosh University, Ghaziabad, Uttar Pradesh, India

Received: 22 May 2017

Accepted: 20 June 2017

\section{*Correspondence:}

Dr. Neelima Agarwal,

E-mail: agarwalneelima2@gmail.com

Copyright: () the author(s), publisher and licensee Medip Academy. This is an open-access article distributed under the terms of the Creative Commons Attribution Non-Commercial License, which permits unrestricted non-commercial use, distribution, and reproduction in any medium, provided the original work is properly cited.

\begin{abstract}
Background: Postpartum iron deficiency anaemia (IDA) is common in women. Most women are treated with either oral iron supplementation or blood transfusion. Hence, the aim of our study was to compare the effect of treatment with either oral ferrous sulphate or intravenous ferrous sucrose on postpartum IDA.

Methods: 100 postpartum women with proven iron deficiency anaemia with hemoglobin $<9 \mathrm{gm} / \mathrm{dl}$ and serum ferritin $<15 \mu \mathrm{gm} / \mathrm{l}$ were included in the study. They were randomized to receive either oral ferrous sulphate $200 \mathrm{mg}$ twice daily for 6 weeks (group 1) or intravenous ferrous sucrose $200 \mathrm{mg}$, two to three doses given on alternate days (group 2). Total iron deficit was calculated using a standard formula. Target hemoglobin was $11 \mathrm{gm} / \mathrm{dl}$. Results were analysed by the students t-test and chi-square test. Hemoglobin, hematocrit, red cell indices and ferritin were measured on day 2-3, 1-2 weeks and 6 weeks postpartum

Results: By 1-2 weeks, hemoglobin level in women treated with intravenous iron had risen from $7.81 \pm 0.849$ to $9.88 \pm 0.760 \mathrm{gm} / \mathrm{dl}$ which was more than those treated with oral iron $(\mathrm{p}<0.01)$; although by 6 weeks, there was no significant difference between the two groups. Ferritin levels rose rapidly in those treated with intravenous iron and remained significantly higher than in those treated with oral iron $(\mathrm{p}<0.01)$.

Conclusions: Intravenous iron sucrose increases the hemoglobin level more rapidly than oral ferrous sulphate in women with postpartum IDA. It also replenishes iron stores more rapidly.
\end{abstract}

Keywords: Ferritin, Iron sucrose, Postpartum iron deficiency anaemia

\section{INTRODUCTION}

Postpartum anaemia is a common problem throughout the world and for most women is self limiting, resolving within a week. For some women however, particularly in resource-poor countries, it is a major cause of maternal morbidity and mortality. ${ }^{1}$ Postpartum haemoglobin $(\mathrm{Hb})$ levels of $<10 \mathrm{~g} / \mathrm{dl}$ are observed in up to $30 \%$ of women, with more severe anaemia $(\mathrm{Hb}<8 \mathrm{~g} / \mathrm{dl})$ seen in $10 \%$. Iron deficiency is the principal cause. This is partly attributable to an iron deficit during pregnancy, caused by the increased iron demands of the fetoplacental unit and an increased maternal red cell mass. ${ }^{2}$
Irrespective of mode of delivery, blood loss is a contributing factor, with $5 \%$ of deliveries involving loss of more than $1 \mathrm{~L}$. It appears to be higher in unfavorable socioeconomic conditions.

The symptoms of postpartum anaemia vary and may include breathlessness, fatigue, palpitations, dizziness, maternal infections particularly of the urinary tract, lactation failure and prolonged hospital stay depending on the severity of blood loss and related anaemia. It has also been shown to be strongly associated with depression, stress and cognitive function in the postpartum period and may result in difficulty for the 
mother to care for her baby, thereby influencing the emotional mother-infant bond.

The standard approach to treatment in the majority of institutions is oral iron supplementation, with blood transfusion reserved for more severe or symptomatic cases. ${ }^{3}$ High doses of oral iron frequently cause side effects, including constipation, nausea and gastric irritation and hence, noncompliance is common. In addition, such therapy has to be given for a long time in cases of severe iron deficiency. Blood transfusions have been used in the treatment of postpartum anaemia, but there are risks associated with its use. Therefore, intravenous iron, alone or in association with recombinant human erythropoietin (rhEPO), has been considered as an alternative in the management of iron deficiency in this setting.

The aim of this study was to compare the efficacy of intra-venous iron sucrose versus oral iron in subjects with post-partum iron deficiency anaemia, and to study the safety and side effects of these two preparations.

\section{METHODS}

The present prospective study was conducted in the Department of Obstetrics and Gynecology, Santosh University, Ghaziabad (U.P., India). This study was done to compare the safety and efficacy of intravenous iron sucrose to oral iron in subjects who displayed postpartum anaemia.

Hundred postpartum anaemic women, aged 18 years or more, with diagnosis of iron deficiency anaemia with hemoglobin of 6-9 g/dl, samples taken at 24-48 hours post-delivery and who demonstrated willingness to comply to research protocol were included in the study. Iron deficiency anaemia was diagnosed if hemoglobin was 6-9 g/d, MCV<78fl, MCH<30pg, serum ferritin <15 microgram/l and microcytic hypochromic to normocytic hypochromic picture on peripheral smear.

Women with hemoglobin $>9 \mathrm{~g} / \mathrm{dl}, \quad$ Ferritin $>15$ microgram $/ 1$, history of intolerance to iron derivatives, peripartum blood transfusion, history of asthma, thromboembolism, seizures, alcohol or drug abuse, and those having signs of infection or evidence of renal or hepatic dysfunction were excluded from the study.

Written informed consent was taken from all the women, satisfying the inclusion criteria. A detailed history, followed by general physical systemic and local examination was done.

Patients were assigned to two groups of 50 each using computer generated random number sequence.

There was no statistical significant difference between two groups with respect to age of the patients, booked/unbooked/registered, socio-economic status, religion and parity, as p-value in all the above parameters was greater than 0.05 (applying Pearson's Chi-square Test) (Table 1).

Table 1: Socio-demographic factors.

\begin{tabular}{|c|c|c|c|c|}
\hline \multirow{4}{*}{$\begin{array}{l}\text { Age } \\
\text { (years) }\end{array}$} & $\begin{array}{l}\text { Sub } \\
\text { group }\end{array}$ & $\begin{array}{l}\text { Oral } \\
\text { group } \\
\mathrm{N}=50\end{array}$ & $\begin{array}{l}\mathrm{I} / \mathrm{V} \\
\text { group } \\
\mathrm{N}=50\end{array}$ & $\begin{array}{l}\text { P- } \\
\text { value }\end{array}$ \\
\hline & $19-24$ & 24 & 19 & \multirow[b]{3}{*}{0.546} \\
\hline & $25-29$ & 19 & 21 & \\
\hline & $\begin{array}{l}30 \text { and } \\
\text { above }\end{array}$ & 7 & 10 & \\
\hline \multirow{3}{*}{$\begin{array}{l}\text { Booking } \\
\text { Status }\end{array}$} & Unbooked & 19 & 24 & \multirow{3}{*}{0.580} \\
\hline & Booked & 13 & 10 & \\
\hline & Regsitered & 18 & 16 & \\
\hline \multirow{2}{*}{ Religion } & Hindu & 34 & 30 & \multirow[b]{2}{*}{0.405} \\
\hline & Muslim & 16 & 20 & \\
\hline \multirow{5}{*}{$\begin{array}{l}\text { Socio- } \\
\text { economic } \\
\text { status }\end{array}$} & Upper & NIL & NIL & \multirow{5}{*}{0.288} \\
\hline & $\begin{array}{l}\text { Upper- } \\
\text { middle }\end{array}$ & 2 & 3 & \\
\hline & $\begin{array}{l}\text { Lower- } \\
\text { middle }\end{array}$ & 10 & 11 & \\
\hline & $\begin{array}{l}\text { Upper- } \\
\text { lower }\end{array}$ & 23 & 14 & \\
\hline & Lower & 15 & 22 & \\
\hline \multirow{4}{*}{ Parity } & P1 & 9 & 8 & \multirow{4}{*}{0.288} \\
\hline & $\mathrm{P} 2$ & 22 & 15 & \\
\hline & P3 & 14 & 16 & \\
\hline & $\geq \mathrm{P} 4$ & 5 & 11 & \\
\hline
\end{tabular}

Baseline investigations done on $2^{\text {nd }}-3^{\text {rd }}$ day of postpartum included complete blood count with RBC's indices (MCV, MCH MCHC) for severity and type of anaemia, peripheral smear for type of anaemia and serum ferritin for iron stores. There was no statistical significant difference between two groups with respect to these investigations.

One group received $200 \mathrm{mg}$ of oral ferrous sulphate tablets twice daily for six weeks. Other group received intravenous iron sucrose in divided doses on alternate days. Dose was calculated by the following formulae:

Weight (in $\mathrm{kgs}) \times($ Target hemoglobin-Actual hemoglobin $) \times 0.24+500 \mathrm{mg}^{4}$

Target hemoglobin was set at $110 \mathrm{~g} / \mathrm{L}$, actual hemoglobin in gram per liter was the patient's hemoglobin level on inclusion; 0.24 was a correction factor and $500 \mathrm{mg}$ for the quantity of stored iron in adults.

Iron sucrose was given in the dose of $100 \mathrm{mg}$ elemental iron, slow intravenous infusions on alternate days (starting from day 2-3 of post delivery). No test dose was required. Both the groups were supplemented with five milligrams of folic acid. Result was compared on day 714 of delivery (i.e. 1-2 -weeks after treatment) in both the 
groups. The rate of improvement was measured in terms of hemoglobin, RBC's indices and general improvement of the patient. At 6 weeks postpartum, the final effect of treatment was judged by repeating all the investigations done as baseline.

\section{Statistical analysis}

To compare the difference in means of various parameters $(\mathrm{Hb}$, serum ferritin etc.) between two groups, over period of time (on day 3, 7-14, 42), student- $t$ test was used. $\mathrm{p}$ - value $<0.05$ was taken as level of statistical significance.

\section{RESULTS}

An increase was seen in the values of hemoglobin, hematocrit, RBC indices and serum ferritin in both the groups. But there was a statistically significant difference between the increase in both the groups, with I.V. group showing much higher values than oral group.

Table 2: Comparison of mean hemoglobin between oral and I/V groups.

\begin{tabular}{|llll} 
& $\begin{array}{l}\text { On } 2^{\text {nd }}-3^{\text {rd }} \\
\text { day }(\mathrm{g} / \mathrm{dll})\end{array}$ & $\begin{array}{l}\text { At } 1-2 \\
\text { weeks }(\mathrm{g} / \mathrm{dl})\end{array}$ & $\begin{array}{l}\text { At } 6 \text { weeks } \\
(\mathrm{g} / \mathrm{dl})\end{array}$ \\
\hline $\begin{array}{l}\text { Oral } \\
\text { group }\end{array}$ & 7.90 & 8.65 & 10.16 \\
$( \pm 0.905)$ & $( \pm 0.849)$ & $( \pm 0.877)$ \\
I/V group & 7.81 & 9.88 & 10.91 \\
& $( \pm 0.849)$ & $( \pm 0.760)$ & $( \pm 0.77)$ \\
\hline p-value & 0.625 & 0.00 & 0.00 \\
\hline
\end{tabular}

An increase in mean hemoglobin was observed from $7.90 \pm 0.905 \mathrm{~g} / \mathrm{dl}$ on day $2-3$ of postpartum to $8.65 \pm 0.849$ $\mathrm{g} / \mathrm{dl}$ at $1-2$ weeks, and to $10.16 \pm 0.877 \mathrm{~g} / \mathrm{dl}$ at 6 weeks postpartum in oral group; whereas from $7.81 \pm 0.849 \mathrm{~g} / \mathrm{dl}$ on day 2-3 of postpartum to $9.88 \pm 0.760 \mathrm{~g} / \mathrm{dl}$ at $1-2$ weeks postpartum and to $10.91 \pm 0.770 \mathrm{~g} / \mathrm{dl}$ at 6 weeks postpartum in I.V. group $(\mathrm{p}$ value $=0.000)($ Table 2$)$.

Table 3: Comparison of mean serum ferritin between oral and I/V groups.

\begin{tabular}{|lll|} 
& $\begin{array}{l}\text { On } 2^{\text {nd }}-3^{\text {rd }} \text { day } \\
(\mu g / L)\end{array}$ & $\begin{array}{l}\text { At } 6 \text { weeks } \\
(\mu g / L)\end{array}$ \\
\hline Oral group & $8.04( \pm 2.144)$ & $23.88( \pm 5.339)$ \\
\hline I/V group & $8.30( \pm 1.461)$ & $58.35( \pm 14.537)$ \\
\hline p-value & 0.146 & 0.00
\end{tabular}

Similarly, there was increase in serum ferritin in both the groups but more in I.V. group. In the oral group, mean serum ferritin on 2nd- 3rd postpartum day was $8.04 \pm 2.144 \mathrm{ug} / \mathrm{L}$ which increased to $23.88 \pm 5.339 \mathrm{ug} / \mathrm{L}$ at 6 weeks postpartum. In I.V. group, mean serum ferritin was $8.30 \pm 1.426 \mathrm{ug} / \mathrm{L}$ on $2^{\text {nd }}-3^{\text {rd }}$ day postpartum which increased to $58.35 \pm 14.537 \mathrm{ug} / \mathrm{L}$ at 6 weeks postpartum. This indicates iron sucrose not only treats but also corrects iron stores which is not seen with oral iron. This observation is highly significant in our study thus indicating its use in post-partum anaemia ( $\mathrm{p}$ value $=0.00$ ) (Table 3).

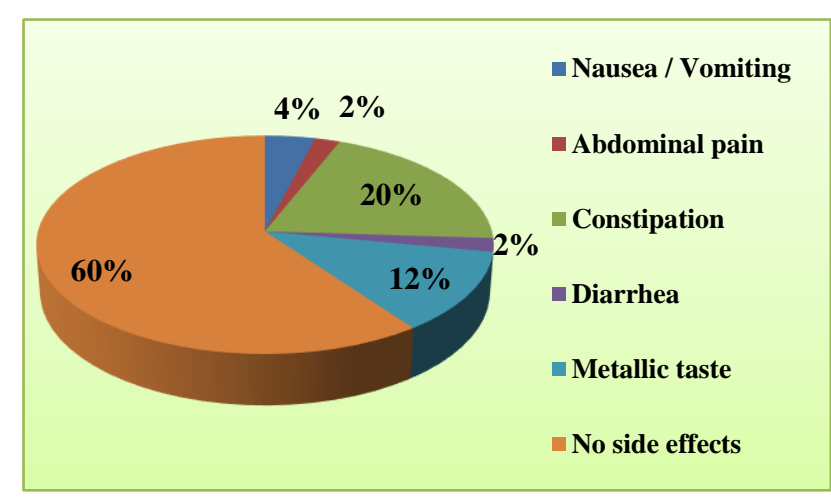

Figure 1: Side effects of oral iron.

Comparing the side effects of oral iron and intra-venous iron in the present study, in the oral group $20 \%$ patients had constipation, $12 \%$ had metallic taste, $4 \%$ had nausea and vomiting, $2 \%$ had abdominal pain and another $2 \%$ had diarrhea. The majority of patients $(40 \%)$ had gastrointestinal side effects (Figure 1). In I.V. group, $4 \%$ patients had mild allergic reaction like rash, flushing and pruritis and 2\% had dizziness. $94 \%$ patients had no serious side effects with iron sucrose. In the present study, I.V. sucrose tolerance seems to be excellent and without adverse effects, in accordance with the literature. (Figure 2).

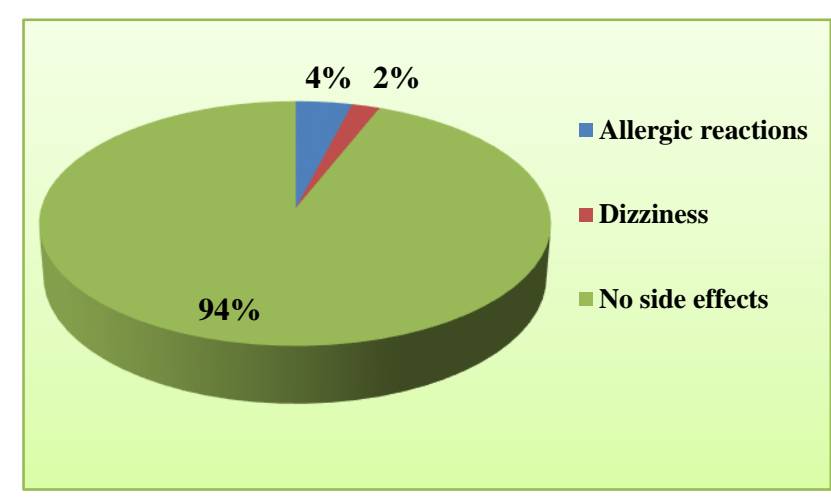

Figure 2: Side effects of I/V Iron.

\section{DISCUSSION}

The socio-demographic factors in present study were comparable to other studies.

The majority of patients were young and belonged to reproductive age group indicating pregnancy as an important factor for iron deficiency anaemia because of increased demand of iron in pregnancy which is not met by normal diet. ${ }^{4-6}$

Most of the women belonged to lower socio- economic class taking diet deficient in essential nutrients and 
minerals and therefore more than $60 \%$ women in our study had anaemia. ${ }^{7}$ Multiparty had been an important risk factor for postpartum anaemia because repeated pregnancies result in depletion of iron stores..$^{6,7}$ The majority of patients in all studies were illiterate or educated up to primary school, which could be due to lower socioeconomic status. Due to lack of education, the patients were not aware of the significance of prenatal care and good nutritious diet. ${ }^{7}$ Women treated with intravenous iron had higher hemoglobin levels in the short term (1-2 weeks postpartum), but no statistical significant difference was observed in patients after 6 weeks in both oral and I.V. iron groups. This indicates the response of iron therapy to be good in both the groups if compliance is assured. ${ }^{2,4-9}$

Serum ferritin is an indicator of iron stores, and decrease in its values indicates depletion of iron stores. In the present study, there was increase in serum ferritin in both the groups but more in I.V. group. This indicates iron sucrose not only treats but also correct iron stores which is not seen with oral iron. This observation is highly significant in other studies thus indicating its use in postpartum anaemia. ${ }^{2,4-9}$ In present study, $40 \%$ of patients with oral iron had gastrointestinal side effects, which were comparable with various studies having $30 \%$ to $33 \%$ of their patients having these side effects. ${ }^{2,4}$ Usually, GI complaints afflict up to $20 \%$ of patients taking ferrous iron salts. In I.V. group, $4 \%$ patients had mild allergic reaction like rash, flushing and pruritis and $2 \%$ patients had dizziness. $94 \%$ patients had no serious side effects with iron sucrose. In the present study, I.V. sucrose tolerance seems to be excellent without adverse effects, in accordance with literature. These observations were comparable to other studies. ${ }^{2,4,6,8}$ The literature documents that intravenous iron sucrose is reasonably well tolerated (35\% of patients have mild side effects) with a low incidence of serious adverse reactions $(0.03-0.04 \%) .{ }^{10}$

\section{CONCLUSION}

Intravenous iron sucrose is an effective alternative to oral ferrous sulphate in the treatment of iron defiency anaemia during postpartum period. It has shorter treatment periods, a lack of gastrointestinal side effects and produces a more rapid increase in hemoglobin concentration and serum ferritin levels than oral ferrous sulphate. At the same time, it is a safe alternative for the treatment of anaemia, being able to reduce the need for blood transfusion and its concomitant side effect. During postpartum period, it helps to rebuild iron stores, helping the symptoms of anaemia to subside at a faster rate and reduces the risk of developing anaemia in subsequent pregnancies. Major advantages are safety, efficacy, compliance, simple mode of administration in an outpatient setting and cost effectiveness because admission is not needed in all cases. Limitations with intravenous iron replacement include the need for medical supervision in the setting of limited health resources.

\section{ACKNOWLEDGMENTS}

Author would like to pay profound regards to co-faculty and patients in the department of Obstetrics and Gynecology of Santosh University for their constant support and immeasurable help.

Funding: No funding sources

Conflict of interest: None declared

Ethical approval: The study was approved by the Institutional Ethics Committee

\section{REFERENCES}

1. Dodd J, Dare MR, Middleton P. Treatment for women with postpartum iron deficiecy anaemia. Cochrane Database Syst Rev. 2004;4: CD004222.

2. Bhandal N, Russell R. Intravenous versus oral iron therapy for postpartum anaemia. BJOG. 2006;113:1248-52.

3. Studd J. Current Progress in Obstetrics and Gynaecology. 2012:1.

4. Bayoumeu F, Buisset C. Iron Therapy in iron deficiency anaemia in pregnancy: intravenous route versus oral route. Am J Obstet Gynecol 2002;186(3):518-22.

5. Al-Momen AK, Al-Meshari A, Al-Nuaim L, Saddique A, Abotalib Z, Khashogji T, Abbas M. Intravenous iron sucrose complex in the treatment of iron deficiency anemia during pregnancy. Eur J Obstet Gynecol Reprod Biol. 1996;69(2):121-4.

6. Broche DE, Gay C, Armand-Branger S, Grangeasse L, Terzibachian JJ. Severe anaemia in the immediate post partum period. Clinical practice and value of intravenous iron. Eur J Obstet Gynecol Reprod Biol. 2005; 123:521-827.

7. Bodnar LM, Cogswell ME. Low income postpartum women are at risk of iron deficiency. J Nutr. 2002;132:2298-302.

8. Perewusnyk G, Breymann C. Parenteral iron therapy in obstetrics: 8 years experience with iron sucrose complex. Br J Nutr. 2002;88:3-10.

9. Westad S, Backe B, Salvesen KA, Nakling J, Økland I, Borthen I, et al. A 12-week randomized study comparing intravenous iron sucrose versus oral ferrous sulphate for treatment of postpartum anaemia. Acta Obstet Gynecol Scand. 2008;87:916-923.

10. Goddard AF, James MW, McIntyre AS. Guidelines for the management of iron deficiency anaemia. $\mathrm{Br} \mathrm{Soc}$ Gastroenterol. 2005;1-6.

Cite this article as: Agrawal N, Sharma P. Intravenous versus oral iron therapy in treatment of postpartum anaemia. Int J Reprod Contracept Obstet Gynecol 2017;6:3454-7. 